\title{
PENGARUH PERUBAHAN STANDAR AKUNTANSI KEUANGAN (SAK) TERHADAP EFISIENSI BANK PERKREDITAN RAKYAT (BPR) DENGAN PENDEKATAN DATA ENVELOPMENT ANALYSIS (DEA)
}

\author{
Suprihadi \\ KAP Suprihadi dan Rekan, \\ Jl Simpang Bunga Andong Selatan No. 26 Malang. Telp. 0811313790
}

\begin{abstract}
The study was conducted to examine the effect of changes in Financial Accounting Standards (SAK) business Rural Bank (BPR), with the enactment of the Financial Accounting Standards Un Accountability Public-entity-(SAK-ETAP) and the Rural Bank Accounting Guidelines (PA-BPR), to BPR efficiency. SAK changes may result in changes to the financial performance of business efficiencies, especially BPR. Efficiency is one of the performance parameters which theoretically can be used as a basis for determining the performance of the bank. Non-parametric approach to Data-Envelopment Analysis (DEA), used as a tool for evaluating the efficiency of $B P R$, with input variables (cash, placements with other banks, fixed assets, other assets, third party financing, interest income, interest expense, expense fees and expenses operational) and the output variable (that is given credit, loans received, and net income). Analysis of the influence of changes in accounting standards on the efficiency of BPR, performed using Analysis of Variance analysis tools-(ANOVA) and regression bootstrap method. The results showed that, for BPR in East Java which has total assets of Rp. 10 (ten) million, changes in accounting standards had no effect on the efficiency of BPR. The condition is caused by, changes in financial accounting standards, fundamentally, is the reclassification and changes in the presentation of accounts in the financial statements BPR.
\end{abstract}

Key words: Financial Accounting Standards, Efficiency, BPR, DEA

\section{PENDAHULUAN}

Regulasi akuntansi di Indonesia terhadap bidang usaha perbankan, khususnya Bank Perkreditan Rakyat (BPR) telah terjadi pada tahun 2010, dengan diterbitkan dan diperlakukannya Standar Akuntansi Keuangan Entitas Tanpa Akuntabilitas Publik (SAK-ETAP) dan Pedoman Akuntansi Bank Perkreditan Rakyat (PA-BPR). Perubahan standar akuntansi keuangan tersebut, mewajibkan BPR untuk merubah prinsip akuntansi, atas akun biaya provisi/transaksi biaya pinjaman, dari dasar kas menjadi dasar akrual. Selain perubahan prinsip tersebut, BPR wajib melakukan reklasifikasi atas akun provisi/transaksi pinjaman yang di terima, dari kelompok kewajiban 
menjadi kelompok aset. Berdasarkan kondisi tersebut, dapat mengakibatkan perubahan terhadap kinerja keuangan khususnya efisiensi usaha BPR.

Efisiensi merupakan salah satu parameter kinerja yang secara teoritis merupakan salah satu kinerja yang mendasari seluruh kinerja sebuah organisasi. Kemampuan menghasilkan output yang maksimal dengan input yang ada, adalah merupakan ukuran kinerja yang diharapkan. Pada saat pengukuran efisiensi dilakukan, bank dihadapkan pada kondisi bagaimana mendapatkan tingkat output yang optimal dengan tingkat input yang ada, atau mendapatkan tingkat input yang minimum dengan tingkat output tertentu. Dengan diidentifikasi alokasi input dan output, dapat dianalisa lebih jauh untuk melihat penyebab ketidakefisienan.

Efisiensi dalam dunia perbankan adalah salah satu parameter kinerja yang cukup populer banyak digunakan, karena merupakan jawaban atas kesulitan-kesulitan dalam menghitung ukuran-ukuran kinerja. Sering kali, perhitungan tingkat keuntungan menunjukkan kinerja yang baik, tidak masuk dalam kriteria "sehat" atau berprestasi dari sisi peraturan.

Industri perbankan adalah industri yang paling banyak diatur oleh peraturanperaturan yang sekaligus menjadi ukuran kinerja dunia perbankan. Capital Adequacy Ratio (CAR), Reserve Requirement (RR), Legal Lending Limit dan kredibilitas para pengelola bank adalah contoh peraturan-peraturan yang sekaligus menjadi kriteria kinerja di dunia perbankan.

Selanjutnya, regulasi yang dibuat oleh profesi akuntansi di Indonesia, yaitu Dewan Standar Akuntansi Keuangan-Ikatan Akuntan Indonesia (DSAK IAI), berupa standar akuntansi keuangan yang diberlakukan sebelum Januari 2010 bagi seluruh perbankan Indonesia termasuk BPR, adalah Pernyataan Standar Akuntansi Keuangan (PSAK) 31 tentang Akuntansi Perbankan. Selanjutnya sejak Januari 2010, diberlakukan PSAK 50-Instrumen Keuangan: (Penyajian dan Pengungkapan) serta PSAK 55Instrumen Keuangan: (Pengakuan dan Pengukuran), digunakan untuk menggantikan PSAK 31. Menurut Ratna E Amiaty, Direktur Kredit BPR dan Usaha Mikro Kecil dan Menengah (UMKM) Bank Indonesia, penerapan PSAK 50 dan PSAK 55 bagi BPR, dipandang tidak sesuai dengan karakteristik operasional BPR, dan memerlukan biaya yang besar, dibandingkan dengan manfaat yang diperoleh, maka BPR memerlukan standar akuntansi keuangan yang sesuai. DSAK-IAI selain menerbitkan PSAK 50 dan PSAK 55, pada bulan Mei 2009 juga menerbitkan Standar Akuntansi Keuangan Entitas 
Tanpa Akuntabilitas Publik (SAK-ETAP). DSAK-IAI dalam SAK-ETAP menyatakan bahwa, SAK-ETAP dapat diberlakukan bagi entitas yang memiliki akuntabilitas publik signifikan, sepanjang otoritas berwenang mengatur penggunaan SAK-ETAP.

Berdasarkan hal tersebut di atas, Bank Indonesia (BI) sebagai otoritas yang berwenang terhadap Bank Perkreditan Rakyat (BPR), telah menerbitkan Surat Edaran No. 11/37/DKBU pada tanggal 31 Desember 2009, yang menetapkan bahwa standar akuntansi keuangan bagi BPR adalah SAK-ETAP. Hal tersebut ditindaklanjuti, dengan diterbitkannya Surat Edaran Bank Indonesia No. 12/14/DKBU pada tanggal 1 Juni 2010, yang menetapkan penggunaan Pedoman Akuntansi Bank Perkreditan Rakyat (PA-BPR), dan diberlakukan sejak 1 Januari 2010, menggantikan Pedoman Akuntansi Perbankan Indonesia (PAPI). PA-BPR merupakan penjabaran lebih lanjut, mengenai prinsip dan substansi pengaturan dalam SAK-ETAP, untuk membantu BPR dalam mencatat transaksi perbankan dan ketentuan perbankan serta menyusun laporan keuangan BPR.

SAK-ETAP dan PA-BPR, diberlakukan sejak Januari 2010 dengan melakukan penyesuaian, atas laporan keuangan BPR tahun 2009. Sesuai surat edaran Bank Indonesia pada tanggal 1 Juni 2010, laporan keuangan tahun 2008 disajikan berdasarkan PSAK 31 dan PAPI. Laporan keuangan tahun 2009 yaitu; neraca, disesuaikan dengan SAK-ETAP dan PA-BPR, sedangkan laba rugi, disajikan sesuai PSAK 31 dan PAPI. Laporan keuangan tahun 2010, disajikan sesuai dengan SAK-ETAP dan PA-BPR. Berdasarkan kondisi tersebut, laporan keuangan BPR yang dijadikan obyek dalam penelitian ini adalah, laporan keuangan tahun 2008, 2009 dan 2010.

Penelitian terdahulu yang berkaitan dengan pengaruh regulasi oleh profesi akuntansi, berupa kebijakan dan standar akuntansi baru antara lain; penelitian yang dilakukan oleh; Lev (1979), Demirgüç-Kunt, Laeven dan Levine (2003), Angel, Haber dan Musacchio (2008), Anggraeni dan Trisnawati (2008), dan McKenna (2010). Hasil penelitian tersebut menunjukkan bahwa, perubahan kebijakan dan standar akuntansi baru berpengaruh terhadap kinerja keuangan obyek penelitian.

Selanjutnya, penelitian dalam bidang perbankan, umumnya menggunakan rasio keuangan sebagai variabel pengukur kinerja bank yang menjadi sampel penelitian. Penelitian yang menggunakan rasio keuangan diantaranya dilakukan oleh; Payamta dan Machfoedz (1999), Utomo (2003), Surbakti, Idrus dan Hariadi (2004), Taswan (2006:245), Merkusiwati (2007), dan Setiawan (2007. Hasil penelitian menunjukkan 
bahwa, rasio keuangan dapat digunakan untuk mengevaluasi kinerja keuangan perbankan.

Secara umum, kinerja suatu bank diukur dengan rasio-rasio keuangannya seperti; rasio kecukupan modal (CAR-capital adequacy ratio), loan to deposit ratio (LDR), rasio return on risked assets (RORA), net profit margin (NPM), return on assets (ROA). Analisis yang berkaitan dengan rasio-rasio ini, dalam ketentuan Bank Indonesia (BI), dikenal dengan istilah analisis CAMEL (Capital Adequacy; Assets; Management; Earnings; dan Liquidity). Rasio-rasio tersebut bila dicermati lebih seksama, maka secara langsung belum dapat mengukur tingkat efisiensi yang dicapai oleh suatu bank. Sebaliknya, rasio-rasio ini sering dikaitkan dengan tingkat kesehatan atau prediksi kegagalan dalam bisnis perbankan. Dengan demikian, analisis tingkat efisiensi bank masih perlu dilengkapi dengan metode atau alat ukur yang lebih tepat, agar ukuran kinerja dan tingkat efisiensi yang telah dicapai oleh suatu bank dengan menggunakan rasio CAMEL, akan menjadi lebih mantap dan meyakinkan.

Astawa (2003), melakukan penelitian dengan mempergunakan alat analisis yang berbeda dengan penelitian sebelumnya. Peneliti ini menggunakan analisis Data Envelopment Analysis-(DEA), untuk melengkapi hasil penelitian yang bertopik analisis CAMEL sebelumnya.

Berbeda dengan penelitian sebelumnya, penelitian ini akan melakukan analisis tingkat efisiensi Bank Perkreditan Rakyat (BPR), berdasarkan fenomena perubahan standar akuntansi keuangan pada tahun 2010, dengan menggunakan model Data Envelopment Analysis (DEA). Dalam analisis efisiensi dengan model DEA, akan menggunakan variabel gabungan, antara variabel input dan output yang dikelola suatu BPR. Dengan analisis efisiensi bank berdasarkan model DEA, akan diperoleh suatu gambaran yang lebih jelas tentang variabel-variabel yang menyebabkan suatu bank menjadi tidak efisien. Model analisis ini sebagai kelanjutan dari model analisis rasio-rasio keuangan termasuk model CAMEL.

Penelitian untuk menilai tingkat efisiensi dengan menggunakan alat analisis DEA, diantaranya dilakukan oleh; Grigorian dan Manole (2002), Feroz, Kim, dan Raab (2003), Hadad, Santoso, Ilyas dan Mardanugraha (2003), Galagedera dan Edirisuriya (2004), dan Fiorentino, Karmann dan Koetter (2006). Hasil penelitian menunjukkan bahwa analisis DEA, dapat dipergunakan untuk mengukur efisiensi. 
Sesuai dengan Frontier Analyst - Version 3 (2003), analisis efisiensi perbankan berdasarkan metode DEA, mampu memberikan suatu penjelasan yang melengkapi analisis rasio CAMEL. Analisis DEA, juga mengukur variabel-variabel yang menyebabkan suatu bank menjadi tidak efisien dan dapat mengalami ketidaksehatan secara sistematis, dan komprehensif untuk membantu manajemen meningkatkan kinerja organisasi dalam hal efisiensi.

Selanjutnya, penggunaan metode DEA, menurut Fiorentino dkk. (2006), lebih sensitif dalam mengukur status efisiensi perbankan, sedangkan menurut Feroz dkk. (2003), pendekatan analisis DEA dapat melengkapi hasil analisis rasio keuangan tradisional.

Berdasarkan kondisi di atas, bahwa telah terjadi perubahan standar akuntansi keuangan terhadap BPR pada tahun 2010, dan penggunaan metode DEA dalam mengukur efisiensi suatu BPR, yang dilakukan dengan pengkombinasian variabelvariabel input dan output yang berbeda dengan penelitian sebelumnya, merupakan kondisi yang mendorong penelitian ini dilakukan, untuk mengetahui pengaruhnya terhadap efisiensi BPR.

Secara lebih terinci, perubahan mendasar dengan diterapkannya standar akuntansi keuangan baru adalah, berubahnya akun-akun tertentu dalam pengakuan dan penyajian laporan keuangan yaitu; Kredit yang diberikan, Pinjaman yang diterima, Beban provisi, Pendapatan bunga, dan Beban bunga. Hal yang lainnya adalah, bagi suatu BPR untuk dapat bertahan hidup dan memiliki keunggulan daya saing yang tinggi, harus mampu mencapai kinerja yang efisien dan sehat, sehingga akan mampu menjalankan fungsi intermediasi secara optimal.

\section{METODE PENELITIAN}

\section{Jenis Penelitian}

Penelitian ini didasarkan pada asumsi bahwa, fakta bersifat independen, sehingga dapat menguji realitas fakta secara obyektif, terbatas pada dimensi tunggal, bebas nilai dan tidak bias. Cara pandang dalam memahami dan memecahkan suatu permasalahan berdasarkan paradigma positivis (positivist) atau empirisis (empiricist), yaitu menekankan pada pengujian teori-teori melalui pengukuran variabel-variabel penelitian dengan angka dan menganalisa data dengan prosedur statistik. Indriantoro 
dan Supomo (2002:12) menyatakan bahwa asumsi dan cara pandang seperti ini termasuk dalam paradigma kuantitatif (quantitative paradigm).

Penelitian ini berusaha untuk menjelaskan sifat hubungan tertentu, atau menentukan perbedaan antar kelompok atau kebebasan (independensi) dua atau lebih faktor dalam suatu situasi. Sekaran (2006:164) menggolongkan penelitian ini termasuk dalam jenis penelitian yang menguji hipotesis (hypothesis testing/hypothetical research), yang bertujuan untuk menawarkan pemahaman yang lebih baik mengenai hubungan yang eksis antar variabel.

Data yang digunakan adalah, data yang sudah ada dan terdokumentasi untuk diolah dalam pemecahan permasalahan. Cara ini dikenal dengan documentary research atau historical research. Dengan demikian, penelitian ini dirancang sebagai penelitian kuantitatif hipotesis dokumenter (documentary quantitative hypothethical research).

\section{Populasi dan Sampel Penelitian}

\section{Populasi}

Populasi adalah suatu pengertian abstrak yang menunjukkan totalitas dari seluruh obyek penelitian. Sedangkan ukuran populasi adalah banyaknya obyek penelitian yang secara konseptual bisa diamati (Sumodiningrat, 1999:3).

Populasi dalam penelitian ini adalah Bank Perkreditan Rakyat (BPR), yang telah beroperasional di Jawa Timur pada periode tahun 2008 - 2010. Periode tahun penelitian didasarkan pada kondisi, pemberlakuan SAK-ETAP dan PA-BPR, untuk usaha BPR. Sesuai surat edaran Bank Indonesia pada tanggal 1 Juni 2010, laporan keuangan tahun 2008 disajikan berdasarkan PSAK 31 dan PAPI dan laporan keuangan tahun 2009 yaitu; neraca disesuaikan dengan SAK-ETAP dan PA-BPR, sedangkan laba rugi disajikan sesuai PSAK 31 dan PAPI, laporan keuangan tahun 2010 disajikan sesuai dengan SAK-ETAP dan PA-BPR. Dengan demikian laporan keuangan BPR yang dijadikan obyek dalam penelitian ini adalah, laporan keuangan tahun 2008, 2009 dan 2010. Jumlah BPR yang aktif beroperasi dan tercatat di daftar perbankan Bank Indonesia (BI) hingga saat ini berjumlah 337 BPR.

\section{Sampel Penelitian}

Konsep sampel erat dengan konsep populasi. Arikunto (2006:113) menyatakan bahwa, sampel adalah bagian atau wakil dari populasi yang diteliti. Sedangkan 
Sumodiningrat (1999:4) menyebutkan bahwa, sampel merupakan himpunan obyek pengamatan yang dipilih dari populasi, dan banyaknya obyek pengamatan dalam sampel disebut ukuran sampel.

Sampel minimum dalam penelitian ini menggunakan pendekatan KrejcieMorgan (Krejcie dan Morgan, 1970), dengan ketentuan umum sebagai berikut :

1. Tujuan penelitian ini untuk mengambil sampel berdasarkan bentuk keragaman populasi. Populasi BPR yang akan diteliti adalah BPR yang beroperasional di Jawa Timur, dengan total aset konsisten sebesar Rp. 10 (sepuluh) milyar ke atas, selama periode penelitian yaitu; 2008-2010. Jumlah populasi BPR secara keseluruhan adalah 337 (tiga ratus tiga puluh tujuh), dan populasi BPR dengan total aset di atas Rp. 10 (sepuluh) milyar berjumlah 107 (seratus tujuh).

2. Populasi BPR (secara keseluruhan termasuk BPR yang memiliki total aset di atas Rp. 10 (sepuluh) milyar) masing-masing telah diketahui angka pastinya (pengamatan dan seleksi selama 2008-2010 dari publikasi BI), maka keragaman populasi disimpulkan bukan sebagai varians, tetapi proporsi.

3. Nilai error (galat) pendugaan yang digunakan dalam penelitian sebagai toleransi kesalahan pendugaan proporsi populasi adalah $10 \%$.

4. Tingkat keandalan rumus Krecjie-Morgan ditetapkan sebesar 95\%. Dengan tingkat keandalan (signifikansi) Krecjie-Morgan $\alpha=0,05$, sehingga, nilai kritis untuk distribusi $\operatorname{chi}=1,96$ (Santoso, 2010:182).

Setelah mengadaptasi ketentuan pendekatannya, maka sampel minimum dapat dihitung dengan rumus sebagai berikut (Krejcie dan Morgan, 1970):

$$
n=\begin{gathered}
\chi^{2} \cdot N \cdot P(1-P) \\
(N-1) \cdot d^{2}+\chi^{2} \cdot P(1-P)
\end{gathered}
$$

Di mana:

$$
\begin{aligned}
& \mathrm{n}=\text { ukuran sampel } \\
& \mathrm{N}=\text { ukuran populasi }=107 \\
& \quad 2=1,98=3,841 \\
& \mathrm{P}=\text { proporsi populasi adalah } 107 / 337=0.317507 \\
& d=\text { nilai error } 0,1^{2}=0,01
\end{aligned}
$$


Berdasarkan angka-angka di atas, setelah diperhitungkan dalam rumus, maka jumlah sampel :

$$
\mathrm{n}=\frac{3,841 \times 107 \times 0,31(1-0,31)}{(107-1) 0,01+3,841 \times 0,31(1-0,31)}=68
$$

Hasil perhitungan untuk pengambilan jumlah sampel minimum dengan rumus Krecjie-Morgan di atas, adalah sebanyak 68 (enampuluh delapan) BPR, dan menurut ketentuan rumus tersebut telah mewakili ukuran populasi BPR dengan total aset di atas Rp.10 (sepuluh) milyar, dengan tingkat keandalan $\alpha=0,05$ dan kesalahan pendugaan 0,1 .

Penentuan populasi BPR dengan total aset di atas Rp. 10 (sepuluh) milyar sebanyak 107 (seratus tujuh) diperoleh dari proses pemilahan data sebagai berikut:

1. Bank yang berstatus sebagai Bank Perkreditan Rakyat (BPR) dan telah beroperasi selama tahun 2008, tahun 2009, dan tahun 2010.

2. BPR sebagaimana disebutkan pada poin 1 di atas, dikelompokkan menurut kantor wilayah (Kanwil) Bank Indonesia yang menjadi wilayah kerjanya di Jawa Timur, yaitu Kanwil ; Kediri, Malang, Jember dan Surabaya.

3. Semua BPR (sampel penelitian) telah menerbitkan laporan keuangan mulai tahun $2008-2010$.

Rasionalisasi populasi BPR dibedakan menjadi populasi yang memiliki total aset di atas Rp. 10 (sepuluh) milyar, bertujuan untuk menghindari bias karena perbedaan ukuran (size effect) BPR, selain hal tersebut BPR dengan total aset di atas Rp. 10 (sepuluh) milyar wajib mempublikasikan laporan keuangan auditan (Peraturan Bank Indonesia (PBI) No. 8/20/PBI/2006).

Susunan data sampel penelitian dari penelitian terdahulu, antara lain; Casu dan Molineux (1999), Xue dan Harker (1999), mempergunakan tidak lebih dari 100 unit. Sementara, Grigorian dan Manole (2002) dari keseluruhan 706 unit, selanjutnya masih dikelompokkan lagi (pooled) menjadi 14 wilayah (berdasarkan negara-negara di Eropa Timur).

Berdasarkan kondisi tersebut di atas, maka penelitian ini mendapatkan range sampel minimum dan maksimum, antara 68 sampai dengan 100 BPR. Selain acuan tersebut, dengan mempertimbangkan kondisi data yang telah terkumpulkan, maka jumlah sampel yang disertakan dalam analisa sebanyak 72 BPR, dengan beberapa rasionalisasi sebagai berikut: 
1. BPR yang tidak memiliki saldo pinjaman yang diterima (PYD) pada neraca, tidak disertakan di dalam pemilihan sampel, dikarenakan variabel PYD dalam analisa sebagai variabel input DEA, maupun analisa-analisa untuk pengujian hipotesis, ketika bersaldo (bernilai) nol (0), akan sulit dibandingkan dengan data yang lain.

2. BPR yang melaporkan kerugian, tidak disertakan dalam sampel yang dianalisa, dikarenakan BPR yang mengalami laba tahun berjalan yang negatif, akan berbeda efisiensinya dengan efisiensi BPR yang tidak rugi. BPR yang rugi akan efisien dalam hal menutup kerugian tersebut, namun bukan efisien dalam rangka meningkatkan pertumbuhan output pada periode berikutnya.

3. Penyepadanan dengan jumlah BPR dengan nilai aset di atas Rp.10 (sepuluh) Milyar, pada wilayah kerja Bank Indonesia (BI) yang paling sedikit, yaitu BI wilayah kerja Jember sebanyak 18 BPR.

Hasil jumlah sampel terpakai dalam analisa sesuai dengan pemetaan wilayah kerja Bank Indonesia (BI) di Jawa Timur, disajikan sebagai berikut:

Tabel 1

Rekapitulasi BPR Sampel per Wilayah Kerja BI

\begin{tabular}{|l|c|c|c|c|c|}
\hline Wilayah Kerja & Jember & Malang & $\begin{array}{l}\text { Surabay } \\
\text { a }\end{array}$ & $\begin{array}{l}\text { Kedir } \\
\text { i }\end{array}$ & Total \\
\hline Jumlah Populasi & 18 & 27 & 30 & 32 & 107 \\
\hline \% distribusi & 17 & 25 & 28 & 30 & 100 \\
\hline Yang masuk sampel penelitian & 18 & 18 & 18 & 18 & 72 \\
\hline $\begin{array}{l}\text { \% pengurangan dari jumlah } \\
\text { populasi }\end{array}$ & 0 & 33,33 & 40 & 44 & 33 \\
\hline
\end{tabular}

\section{Data Penelitian}

Penelitian ini menggunakan data sekunder, yaitu data yang diperoleh dari terbitan/laporan suatu lembaga (Algifari, 1997:10). Data sekunder berupa laporan publikasi BPR-BPR yang dihimpun oleh Bank Indonesia dan dipublikasikan oleh bankbank yang bersangkutan, melalui situs resmi Bank Indonesia atau penerbitan resmi Bank Indonesia. Teknis mengumpulkan data sekunder yang digunakan dalam penelitian ini adalah, penelusuran dengan Komputer - computer based data (Indriantoro dan Supomo 2002:151). Dengan demikian penelitian ini sebagian besar mengumpulkan data yang berbentuk dokumen-dokumen atau file-file data elektronik (database) yang tersedia, untuk memperoleh data dari BPR yang menjadi sampel penelitian. 
ANALISA DATA

Analisis Efisiensi BPR dengan Metode Non-Parametrik DEA

\section{Skor Efisiensi}

Pengelompokan status efisien dan tidak efisien pada masing-masing BPR sampel, didasarkan pada nilai (score) efisiensi yang diperoleh dari hasil analisis dengan alat/metode DEA (Banxia Frontier Analyst Software versi 3). Apabila nilai efisiensi yang diperoleh mencapai angka (100\%), maka BPR sampel tersebut dikatagorikan sebagai BPR berstatus efisien, dan sebaliknya, apabila nilai efisiensi yang diperoleh lebih rendah dari angka $(<100 \%)$, maka BPR dikatagorikan sebagai BPR berstatus inefisien (Hussain dan Jones, 2003).

\section{Potential Improvement/Slack}

Analisis berdasarkan DEA, selain akan menghasilkan nilai efisiensi bagi setiap unit DMU (BPR sampel), juga menyajikan informasi mengenai kondisi setiap variabel input dan output yang memiliki potensi perbaikan (potential improvement/slack), untuk mencapai target nilai efisiensi yang dicapai oleh unit-unit DMU yang lain (benchmark, dengan nilai $100 \%)$. Peluang atau potensi perbaikan pada setiap variabel dimaksud, dinyatakan dalam angka persentase, yang menggambarkan bahwa penggunaan variabel input/output (sumber daya organisasi/BPR) belum optimal, sehingga masih memiliki peluang peningkatan pendayagunaan atas sumberdaya secara relative, sebesar angka persentase tersebut, dibandingkan dengan posisi saat ini (tahun 2010) yang dicapai oleh variabel input-output yang sama pada BPR atau kelompok BPR yang menjadi benchmark-nya.

\section{Input-Output Contribution}

Hasil berikutnya pada analisis DEA adalah, peranan dari masing-masing variabel input-output dalam membentuk nilai efisiensi yang disebut sebagai inputoutput contribution, yaitu informasi mengenai penekanan yang dipergunakan analisis DEA untuk setiap variabel input dan output (Hussain dan Jones, 2003). Kontribusi input-output yang dimaksud, disajikan berupa persentase dari masing-masing variabel input-output, terhadap nilai efisiensi yang dicapai suatu BPR. Dengan demikian akan nampak peranan masing-masing variabel input dalam membentuk nilai efisiensi, 
sedangkan nilai efisiensi yang dicapai akan nampak juga proporsinya pada variabel outputnya.

\section{Statistik Deskriptif}

Statistik deskriptif adalah gambaran secara umum atas data penelitian, yang dihasilkan dari pengumpulan dan peringkasan data, melalui variabel-variabel penelitian. Statistik deskriptif berfungsi untuk menjelaskan atau menggambarkan berbagai karakteristik data, seperti nilai reratanya (mean), nilai maksimum, minimum, dan deviasi standarnya. Dengan memperhatikan statistik deskriptif, maka akan diperoleh suatu gambaran umum tentang kondisi keuangan, berdasarkan komponen variabel yang ditetapkan dalam penelitian dan nilai efisiensi dari masing-masing wilayah kerja bank yang dijadikan sampel penelitian, akan tetapi belum dapat menjadi dasar untuk penguraian kesimpulan.

Penyajian statistik deskriptif dikelompokkan sesuai dengan wilayah kerja BI untuk BPR yang bersangkutan. Data deskriptif masing-masing wilayah kerja BPR meliputi nilai minimum, maksimum, rerata (mean), dan deviasi standarnya, berdasarkan 12 variabel input dan output serta skor efisiensi DEA selama tiga periode (tahun 2008-2010).

Untuk melengkapi pengukuran yang umum dilakukan dalam statistik deskriptif, penelitian menyertakan ukuran M-estimator sebagai alternatif penunjang. Nilai M-estimator adalah pengestimasian rata-rata berdasarkan pembobotan antara nilai trimmed mean dan median data. Fasilitas M-estimator mulai diperkenalkan oleh SPSS mulai versi 11.5, (penelitian ini mempergunakan versi 18), dan penggunaannya sebagai alat alternatif analisa deskriptif didasarkan atas beberapa rasionalisasi:

1. Pengukuran deskripsi data yang lebih sering digunakan adalah mean (rata-rata) dan median (titik tengah). Akan tetapi, untuk mengantisipasi terjadinya kondisi data penelitian terdapat kondisi nilai-nilai data tiap variabel yang cukup menyimpang dari rata-ratanya, maka akan digunakan nilai skewness. Nilai skewness adalah pengukuran asimetri suatu distribusi. Nilai skewness dapat diubah ke angka rasio, dengan membaginya dengan standard error of skewness, yang sebesar 0,536 (hasil perhitungan SPSS). Jika nilai hasil bagi Nilai skewness dengan 0,536 berada di antara $-2 \mathrm{~s} / \mathrm{d}+2$ maka distribusi data adalah normal. 
2. Oleh karena terdapat beberapa variabel dengan kondisi data tidak berdistribusi normal, mean yang dihasilkan dari data yang tidak berdistribusi normal akan tidak cukup menggambarkan ukuran rata-rata data tersebut.

3. Alternatif pertama atas adanya data yang cukup menyimpang saat menghitung mean juga dilakukan dalam penelitian, yaitu mengurutkan data variabel-variabel dari terkecil sampai terbesar, dilanjutkan dengan memotong $5 \%$ dari data terkecil dan $5 \%$ dari data terbesar, kemudian dari hasil yang ada dilakukan perhitungan mean seperti biasa. Perlakuan ini bertujuan untuk membuang (trimming) nilai-nilai data yang cukup menyimpang (karena jauh dari rata-rata). Alternatif ini menghasilkan suatu ukuran yang disebut dengan $5 \%$ trimmed mean.

4. Ukuran trimmed mean akan kurang informatif apabila rata-rata nilai terbesar dan terkecil berubah, karena ukuran trimmed mean tidak bisa mendeteksi adanya perubahan tersebut. Namun, informasi ukuran trimmed mean tetap disertakan sebagai pembanding M-estimator.

Berdasarkan rasionalisasi tersebut, maka ukuran tendensi sentral untuk deskriptif data pada penelitian ini mendasarkan pada nilai M-estimator, bukan mean saja, karena lebih informatif atas adanya kondisi data yang tidak berdistribusi normal. Dapat diinformasikan bahwa tetap disajikan hasil perhitungan mean, median dan 5\% trimmed mean tiap variabel sebagai pembanding M-estimator, dikarenakan nilai $M$ estimator yang cukup mewakili tendensi sentral data (kondisi) variabel, akan berkisar (lebih mendekati) 5\% trimmed mean dan median, daripada mean pada data tidak berdistribusi normal.

\section{Uji Hipotesis}

Hipotesis yang dapat diuji disebut "hipotesis nol" $\left(\mathrm{H}_{0}\right)$, di mana istilah "nol" mengacu pada pemikiran bahwa "tidak ada perbedaan antara nilai yang sebenarnya dengan nilai yang masih dalam pendugaan" (Sumodiningrat, 1999:68). Pengujian dilakukan dengan acuan uji statistik. Pengujian empiris digunakan untuk menguji hipotesis disebut uji signifikansi. Jika nilai dari uji statistik terletak di dalam daerah kritis (daerah penolakan) maka $\mathrm{H}_{0}$ ditolak; ini berarti pernyataan pembanding adalah pernyataan yang benar. Sebaliknya, jika nilai uji statistik terletak di dalam daerah penerimaan, maka $\mathrm{H}_{0}$ diterima dan pernyataan pembandingnya tidak diterima; ini 
berarti pernyataan pembanding adalah pernyataan yang salah (Sumodiningrat, 1999:69).

\section{Uji Hipotesis satu $\left(\mathrm{H}_{1}\right)$}

Untuk menguji hipotesis satu, yaitu untuk mengetahui apakah terdapat perbedaan status efisiensi, antara tahun-tahun sebelum dengan sesudah pemberlakuan perubahan standar akuntansi pada penyajian laporan keuangan BPR. Penelitian mempergunakan uji Analysis of Variance-(ANOVA), yang didefinisikan oleh Santoso (2010:293), sebagai pengujian terhadap sampel yang lebih dari dua untuk mengetahui apakah ada perbedaan yang signifikan (jelas), antara rata-rata hitung kelompok data dari masing-masing sampel tersebut.

\section{Uji Hipotesis Dua}

Penelitian (Grosskopf: 1996), menemukan langkah untuk mengatasi permasalahan utama tersebut, di mana penelitiannya menerapkan analisis regresi. Ide dasarnya dilakukan melalui dua prosedur, yaitu menghitung skor efisiensi terlebih dahulu, kemudian mempergunakan analisis regresi untuk menjelaskan keragaman daripada skor-skor efisiensi tersebut. Regresi Ordinary Least Square (OLS) memiliki keterbatasan dalam analisa keragaman skor efisiensi DEA, dikarenakan skor DEA tersebut sangat berhubungan (berkorelasi) erat dengan variabel bebas pembentuknya (pada proses perhitungan skor DEA pada tahapan analisa data), sehingga nilai estimasi regresi dapat bias (Simar, 1992)

Di sisi lain, terdapat beberapa pendekatan untuk menyelesaikan permasalahan pendugaan keragaman skor efisiensi DEA dengan regresi (Xue dan Harker, 1999; Casu dan Molineux, 1999). Pendekatan ini dilakukan oleh Xue dan Harker (1999): menitikberatkan bahwa skor efisiensi yang dihasilkan model DEA jelas bergantung sama lain dalam analisis statistik. Alasan dependensi ini sebenarnya merupakan fakta yang umum diketahui bahwa skor efisiensi DEA sendiri adalah indeks relatif efisiensi, bukan indeks efisiensi absolut. Dikarenakan keberadaan dependensi inheren di antara skor efisiensi, salah satu asumsi analisis regresi konvensional, independensi di dalam sampel (autokorelasi), dilanggar. Sehingga, prosedur regresi konvensional (uji asumsi klasik) menjadi tidak valid. Untuk langkah alternatifnya, Xue dan Harker (1999) serta Casu dan Molineux (1999) melakukan regresi bootstrap. 
Regresi metode bootstrap adalah metode berbasis komputer untuk melakukan pengukuran akurasi terhadap pendugaan (estimasi) statistik, yang pertama kali diperkenalkan oleh Efron (1979), dan sejak masa itu menjadi alat statistik yang populer dan menyeluruh. Penelitian Simar (1992), kemungkinan merupakan penelitian pertama yang melakukan metode bootstrap untuk menghitung interval keyakinan atas skor efisiensi relatif yang dihasilkan oleh frontier non-parametrik. Semenjak itu, bootstrap dipergunakan untuk membuktikan distribusi empiris atas skor efisiensi pada setiap kasus (pengamatan) dalam sampel penelitian; untuk memperoleh interval keyakinan dan mengukur bias (residu) dari skor efisiensi DEA; dan untuk menganalisa sensitivitas skor efisiensi atas keragaman sampel setelah skor diperoleh dari frontier non-parametrik (Simar dan Wilson, 1995).

Berdasarkan penelitian di atas, penelitian ini menerapkan langkah-langkah berikut ini (Xue dan Harker, 1999; Casu dan Molineux; 1999), dalam menguji hipotesis kedua, yang terdiri atas tiga tahap (sesi):

a. Tahap Regresi OLS (Ordinary Least Squares)

Melakukan regresi konvensional untuk mengetahui pengaruh dari akun-akun yang penyajiannya berubah terhadap efisiensi BPR. Akun-akun yang berubah tersebut dalam permodelan regresi berperan sebagai variabel bebas $(\mathrm{x})$, sementara efisiensi BPR diperoleh dari skor efisiensi analisis DEA berperan sebagai variabel (y). Variabel bebas (x) terdiri atas lima akun yang penyajiannya berubah, yaitu; Kredit Yang Diberikan (KYD), Pinjaman Yang Diterima (PYD), Beban Provisi (PROV), Beban Bunga (INTEREST), dan Pendapatan Bunga (REV). Adapun nilai variabel-variabel bebas ini diproksikan oleh pengukuran berdasarkan rasio growth dari tahun 2008 ke 2009 dan dari tahun 2009 ke 2010.

Pengujian hipotesis dua ini, diawali dengan melakukan terlebih dahulu analisis regresi model OLS (ordinary least squares) atas skor efisiensi DEA sebagai variabel terikat $(y)$, dengan akun-akun yang penyajiannya berubah setelah pemberlakuan standar ETAP dan PA-BPR untuk pelaporan keuangan BPR, sebagai variabel bebas yaitu ; (Kredit yang diberikan pada nasabah (KYD), Pinjaman yang Diterima (PYD), Provisi (PROV), Beban bunga (INTEREST), dan pendapatan bunga (REV)). Skor efisiensi DEA yang digunakan merupakan skor efisiensi yang dihasilkan dari observasi atas sampel (data) laporan keuangan. Dalam persamaan 1 di atas, skor efisiensi sebagai variabel terikat dinotasikan dengan $\theta$. 
Sebelum menguraikan pengaruh variabel bebas dari suatu model regresi, penelitian menginformasikan terlebih dahulu ketentuan asumsi klasik atas nilai residu pengamatan.Pengujian asumsi klasik sebuah model regresi ini antara lain:

1) Menguji asumsi normalitas: penelitian menggunakan baik grafik normalitas (PP Plot) maupun dengan uji statistik non parametrik Kolmogorov Smirnov atas distribusi nilai residual skor efisiensi DEA sebagai variabel $y$.

2) Menguji asumsi linearitas: penelitian membandingkan standar deviasi antara nilai unstandardized predicted value (UPV) dengan unstandardized residuals (UR). Apabila Nilai standar deviasi UPV > standar deviasi UR menunjukkan bahwa asumsi linearitas terpenuhi (Setyadaharma, 2010).

3) Menguji asumsi heteroskesdastis: penelitian mempergunakan uji Glejser, yaitu meregresikan variabel independen terhadap nilai absolut residual model. Apabila koefisien $t$ tidak ada yang signifikan secara statistik $(>0,05)$ membuktikan bahwa nilai residu pada model adalah cenderung homogen, sehingga asumsi heteroskesdastis nilai residu pada suatu model regresi terpenuhi (Setyadharma, 2010).

4) Menguji asumsi multikolinearitas: Untuk mengetahui ada tidaknya gejala multikolinearitas dapat dilihat dari besarnya Variance Inflation Factor (VIF) dan nilai Tolerance (Ghozali, 2009:95). Apabila hasil uji asumsi ini, untuk VIF tidak ada yang bernilai lebih besar daripada sepuluh (10), dan untuk tolerance tidak sampai dengan satu (1), maka pada model OLS tidak terjadi gejala multikolinearitas yang serius.

5) Menguji asumsi autokorelasi.

Alat uji asumsi autokorelasi untuk pengujian first order autocorrelation, karena melibatkan variabel terikat $\mathrm{y}_{\mathrm{t}-1}$ dan $\mathrm{y}_{\mathrm{t}}$ (skor efisiensi DEA pada tahun 2009 dan 2010) dengan variabel bebas yang diukur dari growth nya $\left(X_{t}-X_{t-1} / X_{t-1}\right)$, dengan kata lain terdapat satu unit periode mundur (lag). Alat uji yang umum dipergunakan untuk first order autocorrelation yakni uji Durbin-Watson (DW). Selanjutnya dilakukan perbandingan Nilai DW dengan nilai ketentuan DW Tabel, untuk mengetahui ada tidaknya gejala autokorelasi pada model regresi. 
b. Tahap Penarikan Sampel Bootstrap

Tahapan yang akan dilakukan dalam menganalisis dengan sampel Bootstrap adalah sebagai berikut :

1) Pertama, Menyusun distribusi probabilitas sampel $F$ dengan menambahkan atribut $1 / \mathrm{n}$ pada tiap variabel input-output (Input adalah $\mathrm{CASH}, \mathrm{FA}, \mathrm{OA}, \mathrm{FUND}$, INTEREST, EXPENSE, PYD, PROV, dan REV; sedangkan output adalah PBL, KYD, dan NET INCOME), pembentuk DMU pada analisis efisiensi DEA dalam sampel yang diobservasi $\left(x 1, x 2, \ldots ., x_{n}\right)$, yakni $1 / 72$, di mana sampel penelitian telah disusun dalam baris yang seimbang (4 wilayah kerja BI memiliki proporsi BPR yang sama). Distribusi probabilitas $\mathrm{F}$ dengan $\mathrm{n} 1=1$, dan $\mathrm{n} 2=72$ didapatkan dari jumlah sampel 72 BPR, dengan tahun observasi selama 2 tahun (2009 dan 2010).

2) Kedua, Melakukan prosedur sampel bootstrap, yakni menarik: $c=1.000$ sampel acak dengan ukuran 144 dengan pergantian dari sampel 144 BPR (72 BPR x 2 tahun periode pengamatan).

3) Ketiga, Menghitung kembali skor efisiensi DEA (rerunning analysis) untuk sampel bootstrap yang telah diperoleh sebelumnya. Dari langkah ini akan diperoleh skor efisiensi DEA yang baru, yakni skor efisiensi DEA dari sampel bootstrap yang dinotasikan dengan lambang $\theta b$.

4) Keempat, Melakukan estimasi regresi pada sampel bootstrap dengan persamaan berikut:

$\theta b_{k i}=\beta b_{k 1} \mathrm{gKYD} \mathrm{D}_{k i}+\beta b_{k 2} \mathrm{gPYD} \mathrm{D}_{k i}+\beta b_{k 3} \mathrm{gPROV}{ }_{k i}+\beta b_{k 4} \mathrm{gINT}_{k i}+\beta b_{k 5} \mathrm{gREV}_{k i}+\mathrm{e}_{k i \ldots .}(2)$

Keterangan:

$\theta b \quad=$ skor efisiensi DEA untuk DMU $i$ pada sampel bootstrap $k$ dan $\beta_{k j}(j=$ $1, \ldots 5)$ adalah replika bootstrap untuk $\beta b$ dalam sampel bootstrap $\mathrm{k}$

$\beta b_{k} \quad=$ koefisien parameter regresi bootstrap dalam sampel bootstrap $\mathrm{k}$

$g=$ melambangkan growth untuk masing-masing variabel bebas (KYD, PYD, PROV, INT, dan REV)

e $\quad=$ standard error (nilai residual) $i$ dalam sampel bootstrap $\mathrm{k}$

i $\quad=1,2, \ldots, 144$

$\mathrm{k} \quad=1,2, \ldots, 1000$ 
5) Kelima, mengukur nilai residu estimasi (standard error of estimate) berdasarkan deviasi standar sampel c (replika beta bootstrap):

6) Keenam, menghitung statistik induktif $t$, ( $\left.t_{\text {hitung }}\right)$ dengan:

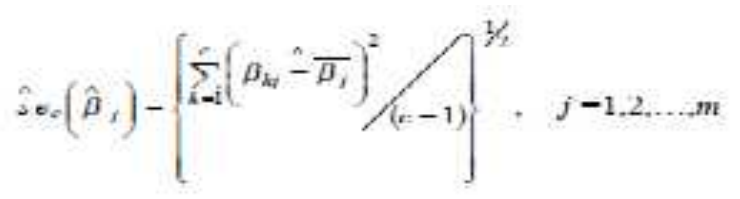

7) Ketujuh, Setelah nilai $t_{\text {hitung }}$ diperoleh, pengujian hipotesis kedua dapat dilakukan dengan ketentuan quick look, yakni signifikansi probabilitas $\alpha=0.05$

$$
t=\frac{\hat{\beta}_{y}}{s e_{c}\left(\hat{\beta_{3}}\right)},
$$

\section{HASIL PENELITIAN DAN PEMBAHASAN}

Analisis data penelitian dengan menggunakan metode non-parametrik Data Envelopment Analysis-(DEA) dalam menilai efisiensi suatu BPR, yang terdiri atas hasil skor efisiensi, potential improvement/(slack), dan input-output contribution, serta statistik deskriptif variabel-variabel input-ouput yang disertakan dalam DEA. Fungsi kedua bab ini adalah, menyajikan hasil pengujian hipotesis satu, berdasarkan uji oneway Analysis of Variance-(ANOVA) atas nilai efisiensi BPR dengan DEA, dan hasil pengujian hipotesis dua dengan regresi bootstrap. Setelah hasil uji hipotesis penelitian diuraikan, bagian bab ini dilanjutkan dengan pembahasan atas keputusan hipotesis penelitian.

\section{Hasil Analisis Efisiensi BPR dengan Metode Non-Parametrik DEA}

\section{Skor Efisiensi}

Dalam mengolah data asli melalui software Banxia Frontier Analyst, data penelitian dirunning berdasarkan masing-masing tahun dengan jumlah BPR yang proporsional, yaitu 72 BPR tiap tahunnya. Penelitian tidak merunning secara keseluruhan total observasi $(72 * 3=216)$. Skore efisiensi didapatkan dengan menggunakan software, apabila nilai efisiensi mencapai angka $(100 \%)$, maka sampel 
BPR dikatagorikan sebagai BPR berstatus efisien, dan sebaliknya, apabila nilai efisiensi lebih rendah dari angka (<100\%), BPR dikatagorikan sebagai BPR inefisien.

Pada tabel 3.1. bagian berikut, penelitian menyajikan jumlah BPR efisien dan inefisien berdasarkan skor efisiensinya.

Tabel 2

Pengelompokkan BPR dalam Status Efisiensi Usaha Tahun 2008-2010

\begin{tabular}{|c|c|c|c|c|c|}
\hline Tahun 2008 & Jember & Malang & Surabaya & Kediri & Total \\
\hline Efisien & 12 & 11 & 15 & 10 & 48 \\
\hline Inefisien & 6 & 7 & 3 & 8 & 24 \\
\hline Total & 18 & 18 & 18 & 18 & 72 \\
\hline Tahun 2009 & Jember & Malang & Surabaya & Kediri & Total \\
\hline Efisien & 14 & 13 & 14 & 9 & 50 \\
\hline Inefisien & 4 & 5 & 4 & 9 & 22 \\
\hline Total & 18 & 18 & 18 & 18 & 72 \\
\hline Tahun 2010 & Jember & Malang & Surabaya & Kediri & Total \\
\hline Efisien & 12 & 14 & 13 & 9 & 48 \\
\hline Inefisien & 6 & 4 & 5 & 9 & 24 \\
\hline Total & 18 & 18 & 18 & 18 & 72 \\
\hline
\end{tabular}

Berdasarkan tabel 3.1., secara umum dapat diinterpretasikan kondisi-kondisi, sebagai berikut:

1. Jumlah BPR yang efisien secara keseluruhan paling banyak terdapat pada BPR wilayah kerja BI Surabaya. Hal ini berarti bahwa, dari keseluruhan BPR yang beroperasi di Jawa Timur, mulai tahun 2008 sampai dengan 2010, kelompok BPR di wilayah kerja BI Surabaya, merupakan BPR paling efisien di antara ketiga wilayah kerja BI lainnya, yaitu; BI wilayah kerja (Kediri, Malang dan Jember).

2. Jumlah BPR baik yang berstatus efisien maupun inefisien dari tahun 2008 sampai dengan 2010 berselisih relatif kecil, dan tidak berbeda secara jelas. Berdasarkan kondisi tersebut dapat diinterpretasikan bahwa, melalui perbandingan BPR-BPR yang sama untuk setiap tahunnya, menghasilkan nilai efisiensi DEA yang tidak jauh berbeda.

Selanjutnya, pengelompokan status efisiensi BPR, juga dilakukan berdasarkan rata-rata skore efisiensi dibandingkan dengan skore efisiensi BPR setiap tahunnya (2008 - 2010). Hasil perbandingan status efisiensi setiap tahun menunjukkan bahwa, pada tahun 2008 jumlah BPR tidak efisien sebanyak 16 BPR, tahun 2009 sejumlah 16 BPR, sedangkan tahun 2010 sebanyak 15 BPR. Berdasarkan kondisi tersebut 
menunjukan bahwa, melalui perbandingan dengan rata-rata skore efisiensi menghasilkan jumlah BPR yang tidak efisien tidak jauh berbeda pada setiap tahunnya.

\section{Potential Improvement/Slack}

Pada tabel 3.2. bagian berikut, penelitian menyajikan potential improvement (slack) bagi BPR-BPR yang inefisien pada tahun 2010.

Tabel 3

Prosentase (\%) Potential Improvement (Slack) pada BPR inefisien 2010

\begin{tabular}{|l|r|r|r|r|r|r|}
\hline Tahun 2010 & Jember & Malang & Surabaya & Kediri & Total & $\begin{array}{l}\text { \%Relatif/ } \\
\text { BPR }\end{array}$ \\
\hline CASH & $(16)$ & $(9,03)$ & $(23,52)$ & $(13,13)$ & $(61,68)$ & $(2,57)$ \\
\hline FA & $(33,77)$ & $(9,45)$ & $(29,91)$ & $(48,81)$ & $(121,92)$ & $(5,08)$ \\
\hline OA & $(75,96)$ & $(65,96)$ & $(34,41)$ & $(37,33)$ & $(213,66)$ & $(8,9025)$ \\
\hline FUND & $(4,24)$ & $(6,72)$ & $(0,63)$ & $(1,37)$ & $(12,96)$ & $(0,54)$ \\
\hline INTEREST & $(18,82)$ & $(11,88)$ & $(10,66)$ & $(13,84)$ & $(55,2)$ & $(2,3)$ \\
\hline EXPENSE & $(34,28)$ & $(7,46)$ & $(9,72)$ & $(43,58)$ & $(95,04)$ & $(3,96)$ \\
\hline PYD & $(37)$ & $(16,13)$ & $(26,94)$ & $(21,17)$ & $(101,24)$ & $(4,21)$ \\
\hline PROV & $(59,35)$ & $(20,78)$ & $(30,68)$ & $(46,05)$ & $(157,68)$ & $(6,57)$ \\
\hline REV & $(15,88)$ & $(4,18)$ & $(5,54)$ & $(15,68)$ & $(41,28)$ & $(1,72)$ \\
\hline PBL & 38,66 & 18,95 & 19,10 & 45,21 & 121,92 & 5,08 \\
\hline KYD & 201,09 & 38,85 & 101,78 & 214,12 & 555,84 & 23,16 \\
\hline NET INC. & 297,88 & 91,25 & 82,14 & 390,81 & 862,08 & 35,92 \\
\hline
\end{tabular}

Keterangan: Apabila total persentase dibagi dengan 24 (jumlah BPR inefisien 2010) maka akan diperoleh angka persentase relatif untuk potensial improvement/(slack) relatif per BPR

Informasi seperti disajikan pada tabel 3.2. di atas, akan bermanfaat bagi manajemen BPR, guna memberi perhatian khusus dan terfokus pada variabel-variabel input-output yang memiliki angka persentase potential improvement/(slack) yang relatif besar. Untuk keseluruhan BPR inefisien di masing-masing wilayah kerja BI, total angka negatif pada setiap nilai variabel input pada bagian tersebut, menunjukkan masih diperlukannya minimalisasi sebesar total angka persentase minus tersebut, saat dibandingkan dengan angka yang dicapai oleh BPR dengan status efisien (benchmarknya), atau seperti yang disajikan Hussain dan Jones (2003) dengan istilah peer based.

\section{Input-Output Contribution}

Pada tabel 3.3. bagian berikut, penelitian menyajikan input-output contribution, pada nilai efisiensi BPR selama tahun penelitian yaitu 2008 - 2010. 
Tabel 4

Persentase Variabel Input-Output Contribution pada Nilai Efisiensi (2008-2010)

\begin{tabular}{|c|c|c|c|c|}
\hline \multicolumn{5}{|l|}{ Bagian I } \\
\hline Wilayah & CASH (i) & FA (i) & OA (i) & FUND (i) \\
\hline Jember & 3,48 & 6,11 & 1,07 & 27,20 \\
\hline Malang & 6,26 & 6,87 & 4,67 & 32,89 \\
\hline Surabaya & 6,13 & 5,60 & 5,98 & 30,00 \\
\hline Kediri & 5,44 & 5,63 & 5,78 & 32,24 \\
\hline \multicolumn{5}{|l|}{ Bagian II } \\
\hline Wilayah & INTEREST (i) & EXPENSE (i) & PYD (i) & PROV (i) \\
\hline Jember & 15,52 & 16,74 & 9,57 & 3,30 \\
\hline Malang & 17,63 & 11,24 & 6,67 & 2,45 \\
\hline Surabaya & 20,74 & 9,02 & 7,07 & 1,78 \\
\hline Kediri & 6,57 & 6,50 & 9,55 & 4,53 \\
\hline \multicolumn{5}{|l|}{ Bagian III } \\
\hline Wilayah & REV (i) & PBL (o) & KYD (o) & NET INC. (o) \\
\hline Jember & 14,67 & 16,30 & 47,22 & 34,83 \\
\hline Malang & 11,33 & 23,81 & 56,40 & 19,78 \\
\hline Surabaya & 11,52 & 22,24 & 45,18 & 30,74 \\
\hline Kediri & 16,74 & 16,04 & 72,89 & 11,07 \\
\hline
\end{tabular}

Berdasarkan tabel 3.3, secara umum dapat diketahui, besaran kontribusi inputoutput dari masing-masing kelompok BPR per wilayah kerja BI, selama tiga tahun periode observasi yaitu; 2008, 2009 dan 2010 yang mengindikasikan kondisi sebagai berikut:

1. Dalam menghasilkan nilai efisiensi, DEA lebih menekankan (mempergunakan) variabel input yang secara relatif persentase kontribusinya lebih tinggi dibanding variabel input yang lain. Secara umum, keseluruhan BPR sampel di keempat wilayah kerja BI, sama-sama memiliki persentase kontribusi variabel input FUND, INTEREST, EXPENSE, dan REV yang relatif lebih tinggi dibanding variabel input CASH, FA, OA, PYD dan PROV dalam menghasilkan skor efisiensi. Akun dana pihak ketiga-(FUND) (menunjukkan operasional BPR dalam menghimpun dana), beban (baik beban bunga (INTEREST) maupun beban non-bunga (EXPENSE), menunjukkan beban yang harus ditanggung BPR dalam usahanya), serta pendapatan bunga (REV) (adalah besaran aliran yang dapat dialokasikan kembali untuk menghasilkan output) lebih diproporsikan oleh DEA dibanding variabel 
input yang lain. Hal ini dapat dipersepsikan bahwa DEA lebih menekankan pentingnya 'akun-akun' yang lebih 'materiil' jumlahnya, dibanding variabelvariabel input pelengkap (CASH, OA, PYD dan PROV).

2. Persepsi yang senada juga dapat diterapkan pada kontribusi variabel output, yaitu secara umum, BPR sampel mengindikasikan kondisi yang lebih berperan dalam ukuran efisiensi adalah, KYD dan NET INCOME dibandingkan PBL. Dengan demikian, DEA lebih menekankan ukuran efisiensi berdasarkan dua output operasional BPR yang paling utama, yaitu kredit yang diberikan (KYD), yang pada akhirnya akan dicerminkan oleh besaran laba bersih periode berjalan (NET INCOME) pada akhir periode. Adapun PBL, yang menunjukkan persentase relatif lebih rendah dibanding kedua variabel tersebut, mengindikasikan bahwa dana 'menganggur' (idle) yang ditempatkan pada bank lain (cukup banyak faktor operasional yang menyebabkan BPR memilih akun ini), tidak cukup peranannya sebagai output dalam mengukur tingkat efisiensi BPR. Kondisi ini mendekati kenyataan, bahwa hasil yang diperoleh dari operasionalisasi KYD, akan lebih bermakna ketika dijadikan sebagai ukuran output (karena memberikan outcome yang lebih materiil), dibandingkan 'hanya' melakukan penempatan atas dana yang tidak produktif (menganggur -idle) - (PBL) pada industri perbankan lain.

Informasi yang lebih terinci atas input-output contribution dari BPR, secara individual untuk masing-masing tahun; 2008, 2009 dan 2010, serta setiap kelompok BPR berdasarkan wilayah kerja BI, pada posisi akhir tahun yang sama disajikan pada Lampiran 2.3. Angka persentase peranan (kontribusi) variabel-variabel input terhadap nilai efisiensi yang dicapai setiap BPR secara individu maupun per wilayah kerja BI, dapat dipersepsikan secara umum sebagai variabel-variabel yang besarannya menyumbang peran secara nyata pada nilai efisiensi, sedangkan persentase kontribusi variabel output merupakan komposisi output, pada nilai efisiensi yang telah dicapai oleh setiap BPR maupun kelompok BPR.

\section{Statistik Deskriptif}

Berdasarkan perhitungan tendensi sentral dengan M-estimator untuk masingmasing variabel, maka dapat dideskripsikan kondisi antara lain sebagai berikut: (Lampiran 3: Rekapitulasi hasil statistik deskriptif 2008-2010) 
1. Pada BPR-BPR wilayah kerja BI Surabaya, secara umum, memiliki nilai variabel input (CASH, FA, OA, FUND, INTEREST, EXSPENSE, dan REVENUE) relatif rendah dibandingkan dengan tiga wilayah kerja BI yang lain, yaitu; Jember, Kediri dan Malang. Sedangkan variabel input PYD dan PROV mempunyai nilai relatif tinggi.

2. Secara umum, variabel pinjaman yang diterima (PYD) yang semakin besar akan diikuti oleh variabel dana pihak ketiga (FUND) yang lebih kecil. Tingginya PYD yang diikuti oleh variabel beban bunga INTEREST, berbanding terbalik dengan besaran INTEREST, yang harus ditanggung variabel FUND.

3. Dengan demikian, BPR-BPR yang berada di wilayah kerja BI Surabaya, lebih efisien dikarenakan, pemerolehan sumber dana yang lebih besar dengan biaya modal lebih murah, dibandingkan dengan BPR-BPR, di 3 wilayah kerja BI lainnya.

4. Sejalan dengan hasil pengujian M-estimator, adalah hasil analisis dengan menggunakan analisa rasio-rasio keuangan. Hasil analisa rasio menunjukkan bahwa, BPR-BPR di wilayah kerja BI Surabaya, memiliki rasio PYD dibandingkan FUND, paling besar, serta rasio INTEREST dibandingkan REV paling kecil, dan rasio NET INCOME dibandingkan KYD, yang besar pula, dibandingkan dengan BPR-BPR, di 3 wilayah kerja BI lainnya.

\section{Hasil Pengujian Hipotesis}

\section{Hasil Pengujian Hipotesis Satu}

Hipotesis pertama $\left(\mathrm{H}_{1}\right)$ menyatakan, terdapat perbedaan status efisiensi pada BPR antara sebelum dengan sesudah diberlakukannya perubahan Standar Akuntansi Keuangan, dari PSAK 31 dan PAPI ke SAK.ETAP dan PA-BPR.

Sebelum disajikan hasil pengujian hipotesis 1, pada tabel 3.4. berikut ini disajikan hasil pengujian berlaku tidaknya asumsi ANOVA dengan Levene Statistic.

Tabel 5

Hasil pengujian Levene Statistic

\begin{tabular}{|r|rr|r|rr|}
\hline Levene Statistic & df1 & df2 & Sig. \\
\hline 0,737 & & 2 & 213 & .480 \\
\hline
\end{tabular}

Dari tabel 5.4. di atas dapat disampaikan bahwa, Levene Test hitung dengan probabilitas (sig) sebesar 0.480 sehingga lebih besar dari 0,05. Dengan demikian asumsi 
ANOVA berlaku. Setelah ketiga kelompok nilai efisiensi DEA variansnya memenuhi asumsi, dapat diuraikan hasil uji ANOVA sebagai dasar keputusan diterima atau ditolaknya hipotesis satu dalam penelitian ini.

Sebagai dasar pengujian, ANOVA menganalisa perbedaan mean nilai efisiensi masing-masing kelompok tahun. Adapun hasil pengujian disajikan sebagai berikut:

Tabel 6

Hasil Perhitungan dengan oneway ANOVA

\begin{tabular}{|l|r|r|r|r|r|}
\hline & \multicolumn{1}{|c|}{$\begin{array}{l}\text { Sum of } \\
\text { Squares }\end{array}$} & Df & Mean Square & F & \multicolumn{1}{c|}{ Sig. } \\
\hline Between Groups & 64.344 & 2 & 32.172 & 0.214 & .808 \\
\hline Within Groups & 32064.292 & 213 & 150.537 & & \\
\hline Total & 32128.637 & 215 & & & \\
\hline
\end{tabular}

Dari tabel 3.5. di atas, hasil perhitungan oneway ANOVA untuk pernyataan $\mathrm{H}_{1}$, dapat disampaikan sebagai berikut : N1 (df untuk numerator) diketahui sebesar 2, sementara N2 (df untuk denumerator diketahui sebesar 213. Maka, angka $F_{\text {tabel }}$ diperoleh dari tabel F signifikansi 0,05 (Junaidi, 2010), untuk N1 = 2; N2 = 213 . Berdasarkan tabel tersebut didapatkan nilai sebesar 3.04. Perbandingan output $F_{\text {hitung }}$ dengan $\mathrm{F}_{\text {tabel }}$ menjadi:

$0,214<3,04 \rightarrow H_{01}$ diterima, artinya ketiga rata-rata observasi identik

Selanjutnya, dari tabel 5.5. di atas dapat disampaikan bahwa, nilai probabilitas (Sig.) sebesar; 0,808, sehingga :

$0,808>0,05 \rightarrow H_{01}$ diterima, artinya ketiga rata-rata observasi identik.

Sehingga, perumusan hipotesis alternatif yang dinyatakan oleh $\mathrm{H}_{1}$ penelitian ini tidak diterima secara statistik. Dengan demikian, tidak terdapat perbedaan rata-rata skor efisiensi antara tahun sebelum dan sesudah pemberlakuan perubahan standar akuntansi pada penyajian laporan keuangan BPR. Hasil ini konsisten dengan (gambaran umum yang diinterpretasikan melalui statistik deskriptif) bahwa BPR-BPR yang mengalami inefisiensi kinerja keuangan di tahun 2008, selanjutnya tetap inefisien pada tahun 2010. Pada tahun 2009 terjadi penurunan jumlah BPR inefisien, disebabkan pada tahun 2009 terjadi ketidak konsistenan pada penerapan standar akuntansi yaitu laporan keuangan neraca dengan dasar PSAK 31 dan PAPI sedangkan laporan laba rugi menggunakan SAK-ETAP dan PA-BPR. Kondisi lainnya, BPR-BPR yang dari awal sudah efisien (di tahun 2008) cenderung dapat mempertahankan efisiensi tersebut. 


\section{Hasil Pengujian Hipotesis Dua}

Hipotesis kedua $\left(\mathrm{H}_{2}\right)$ menyatakan bahwa, terdapat pengaruh perubahan standar akuntansi keuangan terhadap efisiensi pada BPR. Pengujian hipotesis kedua ini dilakukan dengan tahapan-tahapan sebagai berikut :

a. Tahap pertama, Uji Analisis dengan regresi Ordinary Least Squares (OLS)

Pengujian hipotesis dua, diawali dengan melakukan terlebih dahulu, analisis regresi model OLS atas skor efisiensi DEA, sebagai variabel terikat $(y)$, dengan akunakun yang penyajiannya berubah, setelah pemberlakuan standar ETAP dan PA-BPR untuk pelaporan keuangan BPR, sebagai variabel bebas.

Sebelum menguraikan pengaruh variabel bebas dari suatu model regresi, penelitian menginformasikan terlebih dahulu ketentuan asumsi klasik, atas nilai residu pengamatan. Pengujian asumsi klasik sebuah model regresi ini antara lain: (Hasil Pengujian Asumsi Klasik disajikan pada Lampiran 7.2).

1) Asumsi normalitas: Menunjukkan bahwa, skor efisiensi DEA cenderung berpola mengikuti garis lurus di tengah, sementara untuk memperkuat bukti tersebut, nilai Asymp. Sig. Kolmogorov Smirnov Test bernilai 0,65, lebih besar dari 0,05. Selain itu, rata-rata varian skor efisiensi, yang sebenarnya telah diuji sebelumnya pada tahap hipotesis $\left(\mathrm{H}_{1}\right)$ melalui Levene Statistic yaitu sebesar 0,480, mengindikasikan tidak signifikan, artinya varians skor efisiensi sampel terdistribusi normal. Dengan demikian nilai residual pada model regresi terdistribusi normal.

2) Asumsi linearitas: Menunjukkan bahwa, nilai standar deviasi UPV sebesar 0,1147 > standar deviasi UR 0,0222 yang berarti bahwa, asumsi linearitas terpenuhi.

3) Asumsi heteroskesdastis: Menunjukkan bahwa, koefisien $t$ tidak ada yang signifikan secara statistik $(>0,05)$, membuktikan bahwa nilai residu pada model adalah cenderung homogen, sehingga asumsi heteroskesdastis nilai residu pada suatu model regresi terpenuhi.

4) Menguji asumsi multikolinearitas: Menunjukkan bahwa, hasil uji asumsi ini, untuk VIF, tidak ada yang bernilai lebih besar daripada sepuluh (10) dan untuk tolerance tidak sampai dengan satu (1). Dengan demikian pada model OLS tidak terjadi gejala multikolinearitas yang serius. 
5) Menguji asumsi autokorelasi: Hasil pengujian menunjukkan, nilai $\mathrm{DW}=1,855$, dengan nilai ketentuan DW Tabel untuk prediktor $(k)=5$ (variabel bebas), dan kasus (n) =144 (72 BPR $\times 2$ tahun), untuk mengetahui ada tidaknya gejala autokorelasi pada model regresi, dan dari tabel berikut ini menunjukkan tidak ada autokorelasi

Tabel 7.

Uji Autokorelasi

\begin{tabular}{|c|c|c|c|c|}
\hline Pembanding & Nilai & Ketentuan & & Autokorelasi \\
\hline $4-\mathrm{dU}$ & 2,2000 & $\mathrm{DW}<4-\mathrm{dU}$ & $1,855<2,2000$ & Tidak ada \\
\hline $\mathrm{dU}$ & 1,8000 & $\begin{array}{c}\mathrm{dU}< \\
\mathrm{dU}\end{array}$ & $\begin{array}{c}1,8000<1,855 \\
<2,2000\end{array}$ & Tidak ada \\
\hline $\mathrm{dL}$ & 1,6565 & $\mathrm{DW}>\mathrm{dL}$ & $1,855>1,6565$ & Tidak ada autokorelasi positif \\
\hline $4-\mathrm{dL}$ & 2,3435 & $\mathrm{DW}<4-\mathrm{dL}$ & $1,855<2,3435$ & Tidak ada autokorelasi negatif \\
\hline dL dan dU & $\begin{array}{l}1,6565 ; \\
1,8000\end{array}$ & $\begin{array}{c}\text { Jika: } \\
\mathrm{dL}<\mathrm{DW}<\mathrm{dU}, \\
\text { maka tidak dapat } \\
\text { ditentukan (zone } \\
\text { of indecision) }\end{array}$ & $\begin{array}{l}1,855>1,6565 \\
1,855>1,8000\end{array}$ & $\begin{array}{l}\text { Karena DW bernilai lebih } \\
\text { besar, baik dari dL maupun } \\
\mathrm{dU} \text {, maka } \\
\text { "H } \mathrm{H}_{0 \text { autokorelasi }}=\text { zone of } \\
\text { indecision" ditolak. Artinya, } \\
\text { bisa disimpulkan }\end{array}$ \\
\hline
\end{tabular}

Setelah dilakukan uji asumsi-asumsi klasik, maka hasil pengujian model OLS disajikan pada tabel sebagai berikut:

Tabel 8

Signifikasi koefisien $t$ variabel bebas pada model regresi OLS

\begin{tabular}{|c|c|c|c|c|c|}
\hline \multirow[t]{2}{*}{ Model } & \multicolumn{2}{|c|}{$\begin{array}{l}\text { Unstandardized } \\
\text { Coefficients }\end{array}$} & \multirow{2}{*}{$\begin{array}{c}\text { Standardized } \\
\text { Coefficients } \\
\text { Beta } \\
\end{array}$} & \multirow[b]{2}{*}{$\mathrm{T}$} & \multirow[b]{2}{*}{ Sig. } \\
\hline & B & Std. Error & & & \\
\hline (Constant) & .922 & .013 & & 72.773 & .000 \\
\hline Gkyd & .071 & .054 & .135 & 1.317 & .190 \\
\hline Gpyd & .003 & .025 & .013 & .108 & .914 \\
\hline Gprov & .007 & .027 & .031 & .252 & .802 \\
\hline Gint & .024 & .056 & .057 & .431 & .667 \\
\hline Grev & .003 & .046 & .007 & .057 & .954 \\
\hline
\end{tabular}

Berdasarkan hasil pengujian dengan model OLS menunjukkan bahwa, tidak didapatkan adanya variabel yang signifikan secara statistik, yaitu probabilitas t (Sig.) kesemua variabel bebas, tidak ada yang lebih kecil dari 0,05. Keputusan atas diterima tidaknya hipotesis dua penelitian ini, bukan dari hasil pengujian regresi OLS, oleh karena itu, pada bagian berikutnya, menguraikan tahapan yang dilakukan sebagai 
dasar secara keseluruhan atas keputusan diterima tidaknya $\mathrm{H}_{2}$ penelitian. (Hasil pengujian disajikan pada lampiran penelitian - 7.3 output $\mathrm{H}_{2}$ OLS)

b. Tahap kedua, Uji analisis dengan Regresi Bootstrap

Analisis regresi bootstrap, dipergunakan untuk mendapatkan koefisien parameter (koefisien $\mathrm{t}$ ) regresi yang lebih informative, pada kondisi asumsi normalitas yang diragukan akibat permasalahan inheren antar variabel terikat (y). Analisis ini dilakukan dengan nilai koefisien (B/beta) yang sama dengan regeresi OLS, perbedaanya adalah pada Sig. koefisiennya. Hasil output regresi setelah dibootstrap secara otomatis disajikan pada tabel berikut di bawah ini:

Tabel 9

Output regresi Bootstrap (secara otomatis)

\begin{tabular}{|l|r|r|r|r|}
\hline \multicolumn{1}{|c|}{ Model } & B & Bias & Std. Error & Sig. (2-tailed) \\
\hline (Constant) & .922 & .000 & .011 & .001 \\
\hline Gkyd & .071 & .000 & .046 & .052 \\
\hline Gpyd & .003 & .001 & .011 & .762 \\
\hline Gprov & .007 & -.002 & .010 & .691 \\
\hline Gint & .024 & -.003 & .051 & .787 \\
\hline Grev & .003 & .002 & .038 & .425 \\
\hline
\end{tabular}

Berdasarkan pada tabel 3.7. di atas, apabila dibandingkan dengan output regresi OLS (Tabel 5.6), regresi bootstrap berangkat dengan nilai koefisien (B/beta) yang sama. Perbedaanya adalah pada Sig. koefisien tersebut. Dapat diketahui dari output tabel bootstrap secara otomatis, variabel yang mendekati signifikan mempengaruhi (Sig. < 0.05) hanya rasio pertumbuhan KYD, di antara variabel (akun) lain yang penyajiannya berubah setelah pemberlakuan perubahan standar akuntansi keuangan, dari PSAK 31 dan PAPI ke SAK-ETAP dan PA-BPR. Sedangkan dari pengujian secara manual (satusatu) dari c=100 s/d c=1.000, didapatkan variabel bebas yang signifikan probabilitasnya lebih kecil dari 0,05 (Sig. < 0,05) hanya PYD dan PROV. (Hasil pengujian disajikan pada lampiran penelitian - 7.3 output $\mathrm{H}_{2}$ Bootstrap 2a dan 2b)

Berdasarkan hasil pengujian terhadap 5 variabel bebas, yaitu; KYD, PYD, PROV, INTEREST, dan REV, yang mengalami perubahan penyajian setelah perubahan standar akuntansi keuangan, didapatkan hasil pengujian dengan output tabel bootstrap secara otomatis, hanya menghasilkan satu variabel yaitu KYD yang mendekati signifikan, dan hasil pengujian secara manual bootstrap hanya menghasilkan dua 
variabel yang signifikan yaitu PYD dan PROV, yang mempengaruhi secara signifikan terhadap efisiensi BPR. Selain itu, dari pengujian baik secara manual maupun secara keseluruhan (otomatis), diperoleh hasil yang menunjukkan bahwa, tidak semua variabel bebas dengan probabilitas koefisien $t$ (Sig.) yang menghasilkan nilai $t$ (Sig.) kurang dari 0,05. Dengan demikian dapat disimpulkan bahwa, perumusan $\mathrm{H}_{2}$ dalam penelitian ini tidak dapat diterima.

\section{Pembahasan Hasil Penelitian}

Bagian ini menguraikan rasionalisasi secara kualitatif, atas temuan empiris yang dihasilkan melalui prosedur pengujian hipotesis di bagian sebelumnya.

\section{Perbedaan Status Efisiensi Sebelum dan Sesudah Perubahan Standar Akuntansi Keuangan BPR.}

Berdasarkan hasil analisis yang telah dilakukan dengan metode DEA, dan diuraikan sebelumnya, menunjukkan bahwa, perubahan standar akuntansi keuangan yang diterapkan untuk BPR sejak tahun 2010, dibandingkan dengan sebelum dilakukan perubahan standar akuntansi keuangan, yaitu tahun 2008, menghasilkan jumlah BPR yang menjadi sampel penelitian, tidak mengalami perubahan secara signifikan untuk jumlah BPR yang tidak efisien dan BPR yang efisien, pada keempat wilayah kerja Bank Indonesia di Jawa Timur. Dengan demikian hipotisis $1\left(\mathrm{H}_{1}\right)$ ditolak, karena tidak terjadi perubahan jumlah BPR yang tidak efisien, sebelum dan sesudah terjadi perubahan standar akuntansi dan penyajian laporan keuangan.

Kondisi tersebut di atas, sejalan dengan dasar yang dipergunakan oleh Bank Indonesia, untuk mewajibkan BPR menerapkan SAK-ETAP, dengan menerbitkan surat edaran Bank Indonesia tahun 2009, untuk menggantikan Standar Akuntansi Keuangan yang diberlakukan bagi BPR selama ini yaitu PSAK 31, tentang Akuntansi Perbankan yang berlaku bagi seluruh perbankan. Berlakunya PSAK 50 Instrumen Keuangan: Penyajian dan Pengungkapan (PSAK 50) dan PSAK 55 Instrumen Keuangan: Pengakuan dan Pengukuran (PSAK 55), yang menggantikan PSAK 31, maka standar akuntansi bagi perbankan, mengacu pada PSAK yang berlaku. Penerapan PSAK 50 dan PSAK 55 bagi BPR, dipandang tidak sesuai dengan karakteristik operasional BPR, dan memerlukan biaya yang besar dibandingkan dengan manfaat yang diperoleh maka, BPR memerlukan standar akuntansi keuangan yang sesuai. 
Selanjutnya, selain menerbitkan surat edaran untuk mewajibkan pemberlakuan SAK-ETAP, Bank Indonesia juga menerbitkan surat edaran tahun 2010, tentang pemberlakuan PA-BPR, surat edaran dimaksudkan dalam rangka peningkatan transparansi kondisi keuangan Bank Perkreditan Rakyat (BPR), dan penyusunan laporan keuangan yang relevan, komprehensif, andal dan dapat diperbandingkan. Pedoman Akuntansi BPR (PA-BPR) merupakan petunjuk pelaksanaan, yang berisi penjabaran lebih lanjut dari SAK-ETAP.

Hasil penelitian ini tidak sejalan dengan Angel (2008), disebabkan perbedaan fenomena dan obyek penelitian, yaitu; penelitian didasarkan pada fenomena krisis perbankan di Mesiko tahun 1995, dan obyek penelitiannya adalah bank umum di negara yang bersangkutan.

Selanjutnya penelitian ini tidak senada dengan penelitian Mckenna (2010), disebabkan latarbelakang dan obyek penelitian yang berbeda yaitu; adanya reformasi standar akuntansi untuk tujuan pengendalian likuiditas dan permodalan, dan obyek penelitian adalah bank umum.

Hasil penenelitian ini, juga tidak sejalan dengan penelitian yang dilakukan Astawa (2003). Hal tersebut disebabkan latarbelakang yang berbeda, yaitu adanya krisis moneter di Indonesia tahun 1998, serta obyek penenelitian yang berbeda yaitu, Bank Asing, Bank umum dan bank go publik.

Penelitian ini tidak senada dengan hasil penelitian Hadad dkk. (2003), yang dilatarbelakangi terjadinya merger bank, dan obyek penelitian yang berbeda yaitu Bank BUMN dan Bank Swasta Nasional.

Penelitian ini, selain menunjukkan status efisiensi BPR, dengan metode DEA hasil analisis yang lainnya adalah, didapatkan adanya potential improvement/(slack) atas variabel input-output. Secara umum untuk sampel BPR yang tidak efisien, mengacu pada laporan keuangan tahun 2010, sebaiknya melakukan pengurangan (potential slack) untuk sembilan variabel input, khususnya variabel aset tetap (FA) dan aset lain (OA), dikarenakan dana yang tertanam pada aset jenis ini, menjadi tidak produktif, selain itu juga mengurangi beban provisi (PROV), yang berasal dari pinjaman yang diterima (PYD). Selain itu juga meningkatkan (potential improvement) untuk tiga variabel output, dan lebih fokus peningkatan laba bersih (NET INCOME), yang ditunjang dengan jumlah kredit yang diberikan (KYD). Dengan pencermatan pada variabel-variabel 
input dan output tersebut akan dapat membantu pencapaian tingkat status BPR yang efisien.

Selanjutnya, hasil lainnya dari analisis DEA adalah, didapatkannya variabelvariabel input output yang berkontribusi terhadap status efisiensi BPR. Berdasarkan hasil analisis bahwa, variabel input yaitu ; penerimaan dana pihak ketiga (FUND) yang diikuti oleh beban bunga (INTEREST) yang harus ditanggung BPR, memiliki kontribusi yang besar, sedangkan variabel output yaitu : kredit yang diberikan (KYD) dan laba bersih (NET INCOME), memiliki kontribusi yang besar pula, menggambarkan bahwa peranan BPR sebagai intermediasi, sebagai penghimpun dana dari masyarakat dan kemudian menyalurkan kembali, sebagai variabel utama yang berkontribusi terhadap efisiensi BPR.

\section{Pengaruh Perubahan Standar Akuntansi Keuangan terhadap Efisiensi BPR.}

Pengujian pengaruh perubahan standar akuntansi keuangan terhadap efisiensi BPR, dilakukan dengan menguji akun-akun yang penyajiannya berubah sebagai variabel bebas, dengan pemberlakuan standar dan pedoman akuntansi keuangan baru, yaitu SAK-ETAP dan PA-BPR. Akun-akun yang berubah tersebut terdiri dari; (Kredit yang diberikan (KYD), Pinjaman yang Diterima (PYD), Provisi (PROV), Beban bunga (INTEREST), dan pendapatan bunga (REV)) terhadap variabel terikat y (skore efisiensi DEA).

Berdasarkan hasil analisis dan pengujian menunjukkan bahwa, tidak terdapat kondisi, semua variabel bebas yaitu, akun-akun yang berubah, mempengaruhi secara signifikan status efisiensi BPR. Dengan demikian, perumusan hipotesis $\mathrm{H}_{2}$, tidak dapat dibuktikan bahwa, perubahan standar akuntansi keuangan dapat berpengaruh terhadap efisiensi BPR.

Kondisi tersebut konsisten dengan hipotesis $1\left(\mathrm{H}_{1}\right)$ bahwa, perubahan standar akuntansi keuangan BPR pada tahun 2010, tidak mempengaruhi status efisiensi BPR. Hal tersebut mengindikasikan bahwa, latar belakang terbitnya surat edaran Bank Indonesia (BI), yang mewajibkan perubahan standar akuntansi keuangan, dengan memberlakukan SAK-ETAP dan selanjutnya menerbitkan PA-BPR, dalam rangka peningkatan transparansi kondisi keuangan Bank Perkreditan Rakyat (BPR), dan penyusunan laporan keuangan yang relevan, komprehensif, andal dan dapat 
diperbandingkan adalah sesuai. Hal tersebut terbukti dengan pemberlakuan standar akuntansi keuangan yang baru tidak merubah status efisiensi BPR.

Pengkajian lebih mendalam, terhadap penerapan standar akuntansi keuangan dan pedoman akuntansi BPR yang baru menunjukkan bahwa, tidak terdapat perbedaan yang mendasar terhadap perubahan tersebut. Perubahan yang dilakukan pada standar akuntansi dan pedoman akuntansi baru dibandingkan dengan standar akuntansi yang lama adalah, terjadinya reklasifikasi beberapa akun dalam laporan keuangan.

Beberapa akun yang mengalami perubahan antara lain; Kredit yang diberikan (KYD), pada akun ini dalam penyajiannya dilakukan dengan cara mereklasifikasi atas akun pendapatan provisi diterima di muka, yang sebelumnya disajikan sebagai kelompok kewajiban, direklasifikasi pada akun kredit yang diberikan, pada kelompok aset, dengan nama akun baru yaitu, kredit yang diberikan-provisi, dan penyajiannya dikurangkan dari kredit yang diberikan pokok, sehingga dihasilkan saldo kredit yang diberikan bersih.

Selanjutnya, akun pendapatan provisi yang diterima di muka, yang telah digantikan dengan akun baru yaitu kredit yang diberikan-provisi, diamortisasi dengan cara yang sama yaitu, mengamortisasi akun tersebut selama masa kredit yang diberikan, dengan nama akun yang berbeda, yang sebelumnya dengan nama pendapatan provisi digantikan dengan pendapatan bunga-provisi (REV).

Akun lainnya yang mengalami perubahan adalah, akun pinjaman yang di terima (PYD), pada akun ini dalam penyajiannya dilakukan dengan mereklasifikasi atas akun beban provisi (PROV), yang sebelumnya dibebankan langsung dalam laporan laba rugi, selanjutnya disajikan pada neraca dalam kelompok kewajiban, dengan nama akun baru yaitu pinjaman yang diterima-provisi, dan penyajiannya, dikurangkan dari pinjaman yang di terima pokok, sehingga dihasilkan saldo pinjaman yang diterima bersih.

Selanjutnya, akun pinjaman yang diterima-provisi, dilakukan pembebanan secara periodik, dengan mengamortisasi selama jangka waktu pinjaman yang diterima, dengan akun beban bunga-provisi (INTEREST). Kondisi lain menunjukkan bahwa, sesuai data sampel penelitian, akun beban provisi selama periode penelitian didapatkan saldo akhir yang relatif kecil, dibandingkan dengan akun-akun lainnya, dalam laporan laba rugi BPR. 
Hasil penelitian ini menunjukkan bahwa, hipotesis $1\left(\mathrm{H}_{1}\right)$ dan hipotesis $2\left(\mathrm{H}_{2}\right)$, keduanya menghasilkan pembuktian tidak diterima atau ditolaknya hipotesis. Penolakan hasil pengujian terhadap ke dua hipotesis, selain telah didukung dengan hal-hal yang telah disampaikan sebelumnya, hal yang lainnya adalah, penelitian ini telah dilakukan sesuai dengan persyaratan penelitian ilmiah.

Persyaratan penelitian yang dimaksudkan adalah, tentang validitas data penelitian dan pemilihan alat analisis yang dipergunakan. Data penelitian yang dipergunakan adalah data sekunder, berupa laporan keuangan publikasi BPR-BPR, yang dihimpun oleh Bank Indonesia, dan dipublikasikan oleh BPR-BPR yang bersangkutan, melalui situs resmi Bank Indonesia, sehingga validitas data yang dipergunakan adalah data yang valid.

Pemilihan alat analisis DEA, didasarkan pada, saat ini DEA telah berkembang sebagai alat untuk mengevaluasi dan mengembangkan efisiensi kinerja, baik untuk industri manufaktur maupun jasa. Kegunaannya telah secara luas diterapkan pada badan publik, (sekolah, universitas, rumah sakit), usaha bank dan instalasi produksi. Pemilihan alat analisis yang dipergunakan untuk mengukur kinerja adalah efisiensi. Efisiensi merupakan salah satu paramater kinerja yang secara teoritis merupakan salah satu ukuran kinerja yang mendasari seluruh kinerja organisasi. Efisiensi dalam dunia perbankan, merupakan salah satu parameter kinerja yang cukup populer, sehingga lazim dipergunakan, karena dapat memberikan jawaban atas berbagai kesulitan dalam menghitung berbagai ukuran kinerja.

Selanjutnya, hasil pengelompokkan status efisien dan tidak efisien pada masing-masing BPR sampel, yang didasarkan pada nilai (score) efisiensi, yang diperoleh dari hasil analisis, dengan metode DEA (Banxia Frontier Analyst Software versi 3), telah terbukti dan senada dengan hasil analisis yang telah dilakukan dengan menggunakan oneway ANOVA maupun dengan regresi bootstrap.

Hasil analisis dengan menggunakan oneway ANOVA menunjukkan bahwa, tidak terdapat perbedaan, rata-rata skor efisiensi antara sebelum dengan sesudah pemberlakuan perubahan standar dan pedoman akuntansi BPR. Kondisi tersebut sejalan dengan hasil analisis dengan regresi bootstrap, yang menunjukkan bahwa, tidak ada variabel bebas yang berpengaruh secara signifikan terhadap variabel terikat. Hal tersebut berarti, tidak deterimanya hipotesis 1 dan hiptesis 2 yang telah dilakukan 
pengujian, dengan menggunakan dua analiis tersebut, adalah sejalan dengan hasil analisis DEA.

Pembuktian lainnya dilakukan peneliti, dengan menggunakan analisis beberapa rasio keuangan BPR-BPR sampel penenelitian yang menunjukkan bahwa, dari hasil analisis rasio keuangan menunjukkan, BPR di wilayah kerja BI Surabaya, memiliki tingkat efisiensi paling tinggi, dibandingkan dengan 3 wilayah kerja BI lainnya.

Kondisi lain yang mendukung tidak diterimanya hipotesis penelitian ini adalah, pernyataan dari salah satu pengawas Bank Indonesia Wilayah kerja Jember (Bpk. Taufik), bahwa penerapan SAK-ETAP dan PA-BPR, sesungguhnya tidak berbeda secara mendasar, dibandingkan dengan PSAK-31 dan PAPI, yang telah diterapkan sebelumnya karena standar dan pedoman akuntansi yang baru, lebih memudahkan bagi pengawas $\mathrm{BI}$ dan manajemen BPR, dalam hal konsistensi pengakuan dan penyajian terhadap akun-akun tertentu yaitu, akun provisi atas kredit yang diberikan dan provisi atas pinjaman yang di terima. Penyajian akun-akun tersebut pada standar dan pedoman yang baru, disajikan dalam kelompok akun yang sama, sehingga lebih memudahkan semua pihak untuk menilai konsistensi pengakuan dan penyajian dalam laporan keuangan BPR.

\section{SIMPULAN}

Berdasarkan hasil analisis dan pengujian hipotesis, yang telah dilakukan terhadap status efisiensi Bank Perkreditan Rakyat (BPR), di Wilayah kerja Bank Indonesia (BI) Jawa Timur, yang memiliki total aset di atas Rp. 10 (sepuluh) Milyar, dan didasarkan pada fenomena perubahan standar akuntansi keuangan baru yaitu, Standar Akuntansi Keuangan Entitias Akuntabilitas Publik (SAK-ETAP) dan Pedoman Akuntansi Bank Perkreditan Rakyat (PA-BPR), yang diberlakukan mulai tahun 2010, maka simpulan yang disampaikan adalah sebagai berikut : (1) Dengan menggunakan metode Data Envelopment Analysis-(DEA), dapat diketahui besarnya nilai efisiensi masing-masing BPR (sampel penelitian). Hasil analisis menunjukkan, tidak terdapat perbedaan tingkat efisiensi pada BPR yang diteliti (sampel penelitian), antara sebelum dengan sesudah pemberlakuan perubahan Standar Akuntansi Keuangan dari PSAK 31 dan PAPI ke SAK-ETAP dan PA-BPR, (2) Hasil analisis lainnya dengan metode Data 
Envelopment Analysis-(DEA), dapat diketahui variabel-variabel input dan output apa saja yang memiliki peluang perbaikan, untuk diberdayakan secara optimal dalam rangka mencapai status efisiensi BPR, atau dikurangkan pendayagunaannya, guna mencapai status efisiensi masing-masing BPR yang memiliki status tidak efisien. Hasil analisis juga mendapatkan adanya variabel-variabel input output yang memiliki kontribusi dominan terhadap efisiensi BPR, (3) Berdasarkan hasil pengujian dengan model regresi bootstrap, atas 5 (lima) variabel yaitu; Kredit yang diberikan, Pinjaman yang Di erima, Provisi, Beban bunga, dan Pendapatan bunga, yang mengalami perubahan penyajian setelah perubahan standar akuntansi keuangan menunjukkan bahwa, perubahan standar akuntansi keuangan tidak berpengaruh terhadap efisiensi BPR.

Hal tersebut mengindikasikan bahwa, latar belakang terbitnya surat edaran Bank Indonesia (BI) yang mewajibkan perubahan standar akuntansi keuangan dengan memberlakukan SAK-ETAP dan selanjutnya menerbitkan PA-BPR, dalam rangka peningkatan transparansi kondisi keuangan Bank Perkreditan Rakyat (BPR) dan penyusunan laporan keuangan yang relevan, komprehensif, andal dan dapat diperbandingkan adalah sesuai. Hal tersebut terbukti dengan pemberlakuan standar akuntansi keuangan yang baru tidak berpengaruh terhadap skor efisiensi BPR.

Kondisi lainnya adalah, perubahan standar akuntansi keuangan dan pedoman akuntansi baru pada dasarnya melakukan reklasifikasi akun-akun tertentu dan dapat mempermudah menilai konsistensi dalam pengakuan dan penyajian dalam laporan keuangan. Selain dilakukan reklasifikasi akun-akun tertentu, perubahan prinsip akuntansi yang dilakukan terhadap akun yang ditetapkan tidak mempengaruhi terhadap kinerja BPR secara keseluruhan.

Berdasarkan keterbatasan yang telah disampaikan dan temuan hasil pengujian, maka disarankan untuk para pihak untuk memperhatikan beberapa hal sebagai berikut: (1) Peneliti selanjutnya, dalam melakukan penelitian mengenai efisiensi BPR agar lebih komprehensif, sebaiknya untuk mempertimbangkan faktor ukuran usaha dalam mengkaji tingkat efisiensi BPR. Salah satu yang dapat dilakukan adalah, membandingkan efisiensi berdasarkan ukuran BPR sampel penelitian yang memiliki skala usaha (size) nya, baik dengan aset yang bernilai di atas Rp. 10 (sepuluh) Milyar maupun dengan aset bernilai kurang dari Rp.10 (sepuluh) Milyar, (2) Akademisi dan peneliti lainnya, seyogyanya menindaklanjuti, mengenai dampak yang dapat 
didapatkan setelah melewati jangka waktu yang relatif panjang, terhadap pemberlakuan standar akuntansi keuangan yang baru terhadap kinerja BPR, (3) Untuk mendapatkan pemahaman yang lebih mendalam atas metodologi pengukuran efisiensi, penelitian selanjutnya dapat mempertimbangkan penggunaan statistik parametrik dan non-parametrik. Selanjutnya hasil daripada kedua metodologi tersebut untuk dikaji lebih lanjut. Misalnya metodologi parametrik mengukur efisiensi yang disarankan dapat menggunakan Stochastic Frontier Analysis (SFA), sementara, untuk metodologi non-parametrik (yang menjadi topik utama penelitian ini) dapat mengaplikasikan Data Envelopment Analysis (DEA), (4) Untuk penelitian selanjutnya yang (secara khusus) mempergunakan metodologi non-parametrik DEA, diharapkan lebih memperhatikan landasan teori (terkait topik kasus yang diteliti), bagaimana ukuran efisiensi yang lazim digunakan, bagaimana hubungan variabel input-output, sehingga dapat mengklasifikasikan variabel input-output dengan tepat. Hal lainnya adalah, walaupun DEA tidak mensyaratkan secara khusus sebaran (distribusi) data, akan tetapi lebih baik pengukuran data observasi dispesifikkan melalui proksi tertentu misalnya dengan rasio-rasio keuangan, sesuai rasionalisasi berlandaskan teori.

\section{DAFTAR PUSTAKA}

Algifari. 1997. Statistika Induktif untuk Ekonomi dan Bisnis. Yogyakarta: UPP AMP YKPN.

Arikunto, Suharsimi. 2006. Prosedur Penelitian Suatu Pendekatan Praktek. Edisi Revisi. Jakarta: PT. Rineka Cipta.

Ikatan Akuntan Indonesia. 2009. Standard Akuntansi Keuangan: Entitas Tanpa Akuntabilitas Publik. Jakarta

Indriantoro, Nur., dan Supomo, Bambang. 2002. Metodologi Penelitian Bisnis untuk Akuntansi dan Manajemen. Yogyakarta: BPFE.

Krejcie, R.V. and Daryle W.M. 1970. "Ditermining Sample Size for Research Activities", Educational and Psychological Measurment. Vol. 30: 607-610.

Sekaran, Uma. 2006. Research Methods for Business, Widyaningrum, Resthi (copy editor).(2003). 4th Ed". John Wiley \& Sons Inc. Yon, Kwan Men (penerjemah). (2006). Metodologi Penelitian untuk Bisnis, Edisi 4, Buku 1. Jakarta: Salemba Empat. 
Simar, Leopold. 1992. How to Improve the Performances of DEA/FDH Estimators in the Presence of Noise? Belgium: Institut de Statistique Universit'e Catholique de Louvain Louvain-la-Neuve.

Sumodiningrat, Gunawan. 1999. Ekonometrika Pengantar. Yogyakarta: BPFE.

Xue, Mei., and Harker, Patrick T. 1999. Overcoming the Inherent Dependency of DEA Efficiency Scores: A Bootstrap Approach. Wharton: Financial Institutions Center. 